\title{
MEMBANGUN BUDAYA LITERASI BAGI PEGAWAI NEGERI SIPIL DALAM USAHA BELA NEGARA
}

\author{
Yudi Kresnasurya \\ Badan Kepegawaian dan Pengembangan Sumberdaya Manusia Kabupaten Natuna \\ Article history \\ Received: 7 Agustus 2020 \\ Revised : 14 Agustus 2020 \\ Accepted : 21 Agustus 2020 \\ ${ }^{*}$ Corresponding author \\ Yudi Kresnasurya \\ Email : yudiksurya@gmail.com
}

\begin{abstract}
Abstrak
Tulisan ini membahas mengenai pentingnya membangun budaya literasi bagi PNS dalam usaha bela negara. Bela negara merupakan hak dan kewajiban setiap warga negara, dan dapat dilakukan sesuai dengan profesi. Pendekatan yang digunakan dalam tulisan ini bersifat kualitatif. Data - data diambil melalui kajian literatur (studi kepustakaan). Kajian ini memperkuat beberapa hasil penelitian sebelumnya mengenai pentingnya membangun budaya literasi, dalam hal ini untuk usaha bela negara oleh PNS.

Keywords : Budaya Literasi, PNS, Bela Negara
\end{abstract}

\begin{abstract}
This paper discusses the importance of building a culture of literacy for civil servants in the defense of the state. Defending of country is the right and obligation of every citizen, and can be done in accordance with the profession. The approach used in this paper is qualitative. The data is taken through a literature review (literature study). This study reinforces some of the results of previous research in the importance of building a culture of literacy, in this case for state defense efforts by civil servants.
\end{abstract}

Keywords : Literacy Culture, Civil Servant, Defending the Country

(c) 2020 Pusdiklat Perdagangan. All rights reserved

\section{PENDAHULUAN}

Salah satu fungsi Pegawai Negeri Sipil sesuai dengan Undang - Undang Nomor 5 Tahun 2014 adalah sebagai Perekat dan Pemersatu Bangsa. Fungsi tersebut sangat berkaitan dengan upaya - upaya menjaga keutuhan bangsa dan negara Indonesia atau dapat juga disebut usaha bela negara.
Umumnya bela negara dikaitkan dengan perang, senjata, tentara dan polisi. Kalimat bela negara selama ini biasanya banyak diucapkan oleh para politikus dan para pejabat negara. Namun demikian makna bela negara sebenarnya mengandung pengertian yang sangat luas, tidak melulu hanya perang fisik dan tentara atau polisi saja. Pasal 30 UUD 1945 dan Undang - Undang Nomor 23 Tahun 
2019 tentang Pengelolaan Sumberdaya Nasional Untuk Pertahanan Negara menyebutkan bahwa setiap warga negara berhak dan wajib ikut serta dalam usaha bela negara, dimana salah satu pelaksanaannya dapat dilakukan melalui pengabdian sesuai dengan profesi. Pegawai Negeri Sipil (PNS) tentu termasuk di dalamnya.

Pelaksanaan tugas dan fungsi oleh PNS, yang sesuai dengan ketentuan, sudah dapat disebut ikut melakukan usaha bela negara. Kegiatan bela negara akan lebih bernilai bila kualitas pekerjaan yang dilakukan semakin baik. Peningkatan kualitas pekerjaan oleh PNS dapat dilakukan melalui upaya membangun budaya literasi. Menurut Wikipedia yang dimaksud dengan literasi adalah istilah umum yang merujuk kepada seperangkat kemampuan dan keterampilan individu dalam membaca, menulis, berbicara, menghitung dan memecahkan masalah pada tingkat keahlian tertentu yang diperlukan dalam kehidupan sehari-hari. Menurut Permatasari (2015) literasi secara sederhana dapat diartikan sebagai kemampuan membaca dan menulis, namun sekarang sudah memiliki makna yang lebih luas sehingga keberaksaraan bukan lagi bermakna tunggal melainkan mengandung beragam arti (multi literacies) seperti literasi komputer, literasi media, literasi budaya, literasi teknologi, literasi ekonomi hingga literasi moral. Literasi menurut Irianto dan Febrianti (2017) tidak hanya sekedar kemampuan membaca dan menulis, tetapi literasi dapat bermakna melek teknologi, politik, berpikir kritis, dan peka terhadap lingkungan sekitar.

Upaya membangun literasi bagi masyarakat Indonesia dan khususnya bagi para PNS adalah hal yang sangat penting. Harian Republika, 12 September 2015 (dalam permatasari, 2015) menyebutkan Indeks minat baca penduduk Indonesia baru mencapai 0,001 yang artinya bahwa dari setiap 1.000 orang hanya satu orang yang memiliki minat membaca. Keadaaan ini sangat jauh tertinggal bila dibandingkan dengan Amerika Serikat dimana penduduknya terbiasa membaca 10 - 20 buku pertahun, atau Penduduk Jepang yang membaca buku 10 - 15 buku pertahun. Darmayanti (2016) mengatakan kemajuan bangsa tercermin dari giat atau tidaknya budaya literasi masyarakatnya. Untuk indikatornya bisa dilihat dari kualitas sains dalam suatu negara yang diukur dengan jumlah artikel ilmiah yang dipublikasikan

\section{METODOLOGI}

Penelitian ini dilakukan melalui pendekatan kualitatif. Data - data diambil melalui studi kepustakaan dan berasal dari berbagai penelitian serta kajian. Penulis mengkaji kembali kerangka ideal membangun budaya literasi bagi PNS agar kualitas pekerjaan PNS lebih meningkat sehingga memperkuat usaha bela negara di dalamnya.

\section{HASIL DAN PEMBAHASAN Budaya Literasi}

Budaya literasi dapat mempengaruhi kualitas hidup dari suatu bangsa. Bangsa yang maju memulai suatu kegiatan dengan membaca, memahami dan pada akhirnya mempraktekkannya (literasi). Darmayanti (2016) menyebutkan penguasaan literasi informasi bagi masyarakat akan menjauhkan dari kebodohan karena di saat mempunyai suatu masalah masyarakat tahu di mana harus mencari informasi pemecahan masalahnya. Hal ini menandakan bahwa budaya literasi jelas sangat berpengaruh terhadap kemajuan suatu bangsa dan negara. Ainiyah (2017) mengatakan budaya literasi merupakan kegiatan pembiasaan bagi masyarakat untuk mengecek kebenaran informasi yang ada melalui penelusuran literatur baik melalui buku maupun ahli yang berkompeten terhadap informasi atau kajian yang dimaksud.

Upaya membangun budaya literasi bagi suatu masyarakat memang tidak semudah membalikan telapak tangan, perlu waktu yang panjang dan didukung oleh sarana dan prasarana serta kebijakan pemerintah. Faktor utama yang paling mendasar dalam membudayakan literasi adalah adanya kebiasaan untuk membaca. Namun kenyataannya masyarakat masih menganggap aktifitas membaca hanya untuk menghabiskan waktu (killing to time) bukan mengisi waktu (to full time) dengan sengaja. Artinya aktifitas membaca belum menjadi kebiasaan (habit) tetapi lebih banyak hanya kegiatan sekedarnya (Permatasari, 2015). Menurut Haryanti (2014) yang dimaksud dengan budaya literasi adalah melakukan 
kebiasaan berpikir yang diikuti oleh sebuah proses membaca dan menulis sehingga pada akhirnya akan dilanjutkan dengan menciptakan sebuah karya.

Meningkatkan minat membaca sebagai pondasi utama membangun budaya literasi di masyarakat termasuk di kalangan PNS mendapat tantangan yang semakin kuat di zaman milenial ini. Rendahnya minat baca semakin diperburuk dengan hadirnya media media sosial melalui internet. Suroto (2017) mengatakan rendahnya minat baca masyarakat tidak hanya terhadap buku cetak tetapi juga terhadap buku digital, dan dipengaruhi oleh naiknya minat bersosialisasi melalui media sosial seperti facebook, twiter, instagram dan media sosial lainnya. Perlu usaha yang serius untuk meningkatkan minat membaca bagi para PNS sehingga dapat membangun budaya literasi. Mursalim (2017) menjelaskan beberapa langkah yang perlu dilakukan di dalam masyarakat untuk menumbuhkan budaya literasi adalah dengan melakukan pendekatan kultural, seperti :

a. Pengenalan budaya (tradisi / kebiasaan masyarakat)

b. Pengenalan tokoh masyarakat

c. Pengenalan fasilitas yang ada di masyarakat (fasilitas umum)

d. Pengenalan alam dan kondisi lingkungan

e. Pengenalan kearifan lokal

Membangun budaya literasi bagi PNS bisa juga dilakukan dengan mencontoh dari kewajiban siswa sekolah untuk membaca selama 15 menit setiap hari sesuai dengan Pemendikbud Nomor 21 Tahun 2015. Pemerintah baik pusat maupun daerah dapat membuat kebijakan mengenai pembangunan budaya literasi bagi tiap PNS. Kemudian melakukan sosialisasi misal dengan gerakan membaca dunia, atau even - even lain untuk merangsang para PNS menumbuhkan budaya literasi. Kegiatan ini harus didukung dengan fasilitas yang memadai seperti pembentukan perpustakaan di tiap instansi pemerintah. Langkah lain untuk membangun budaya literasi adalah melalui pemanfaatan teknologi internet. Setiap organisasi pemerintah bisa membuat grup media sosial dimana seluruh pegawai menjadi anggota grup tersebut kemudian ditunjuk tim administratornya dengan tugas memberikan literatur seperti bacaan, gambar bahkan video yang menambah pengetahuan bagi para anggotanya. Hal ini penting dalam menghadapi perubahan zaman yang sangat cepat dan untuk memperkuat usaha bela negara. Kementerian Pendidikan dan Kebudayaan (2017) menyebutkan bahwa untuk menunjang suksesnya pembangunan Indonesia di abad ke-21, masyarakat Indonesia harus menguasai enam literasi dasar, yaitu literasi bahasa, literasi numerasi, literasi sains, literasi digital, literasi finansial, dan literasi budaya.

\section{Bela Negara}

Bela negara merupakan gabungan dari dua suku kata yaitu bela dan negara. Kata bela menurut Kamus Besar Bahasa Indonesia bisa bermakna jaga, pelihara, dan rawat. Bila digabung dengan negara bisa dimaknai sebagai usaha untuk menjaga, memelihara dan merawat negara dari segala gangguan dan ancaman sehingga negara tetap dalam kondisi yang aman. Subagyo (2014) menyatakan bahwa bela negara harus dipahami dalam konteks yang luas dimana setiap warga negara merupakan entitas yang hidup di dalam sebuah bangunan negara sehingga secara hakiki warga negara wajib untuk menjaga, memelihara, dan mengayomi setiap pranata, institusi, dan perangkat kelengkapan negara.

Menurut Widodo (2011) yang dimaksud dengan bela negara adalah sebuah sikap dan tindakan warga negara yang dilandasi rasa cinta tanah air, kesadaran berbangsa dan bernegara, keyakinan Pancasila sebagai ideologi bangsa dan negara, kerelaan berkorban guna menghadapi setiap ancaman, tantangan, hambatan dan gangguan (ATHG) baik yang datang dari dalam maupun dari luar yang membahayakan kelangsungan hidup bangsa dan negara, keutuhan wilayah, yuridiksi nasional dan nilai nilai luhur Pancasila dan Undang - Undang Dasar 1945. Kementerian Pemberdayaan Perempuan Dan Perlindungan Anak (2018) mengatakan konsep bela negara modern bukan merupakan sebuah konsep baru yang berlawanan dengan pakem yang sudah dibuat, namun dalam konsep yang baru tersebut dilakukan pembaruan definisi tentang bela negara masa kini dan bagaimana 
menghadapi ancaman per ancaman secara rinci, dan apabila perlu dijelaskan mengenai lingkungan strategis dan konteks politik yang melatarbelakangi adanya ancaman tersebut serta bagaimana ancaman dapat masuk ke tubuh bangsa dan negara Indonesia. Dengan demikian bila ancaman tersebut dapat diidentifikasi maka negara akan mudah dan cepat, tanggap dan senyap dalam melakukan pengawasan dan tindakan serta antisipasi.

Pegawai Negeri Sipil (PNS) memiliki peranan sangat penting dalam usaha bela negara. Pada zaman milenial ini potensi gangguan atau ancaman terhadap negara semakin meningkat dan bervariasi terlebih pada era industri 4.0. Ancaman yang dimaksud adalah teknologi informasi secara global. Setiawan (2018) mengatakan bahwa dampak nyata perkembangan teknologi informasi dan komunikasi antara lain menciptakan kolonialisme. Arus Informasi antara negara maju dengan negara berkembang tidak seimbang, sehingga akan memunculkan kolonialisme (penjajahan arus informasi dan komunikasi). Hal ini tentu dapat menjadi ancaman serius bagi negara.

Teknologi informasi dengan dukungan layanan internet yang semakin mengglobal tidak bisa lagi dibendung. Hal ini seharusnya dapat dimanfaatkan, namun kenyataan memperlihatkan sebaliknya. Berbagai kasus kejahatan seperti ucapan kebencian, penyebaran konten negatif, mengadu domba, ucapan bohong / hoax, dan hal - hal negatif lainnya tumbuh subur sejalan kemajuan teknologi informasi. Kemenkominfo dalam Republika.co.id menyebutkan ada sekitar 800.000 situs penyebar hoax di Indonesia. Badan Intelijen Negara dalam Kompas.com menyebutkan $60 \%$ konten media sosial berisi hoax. Hal ini tentu sangat berpotensi mengancam keamanan dan keselamatan negara dan bangsa.

Perlu adanya kewaspadaan dan tindakan yang tepat dalam mengatasi hal - hal negatif di atas. Disinilah peran aktif PNS sangat diharapkan. Wewenang yang dimiliki oleh PNS seperti dalam merencanakan, membuat, melaksanakan, mengendalikan, mengawasi dan mengevaluasi kebijakan pemerintah harus serta merta menjadi kegiatan yang bernilai bela negara. PNS harus menyadari dan memahami berbagai jenis ancaman tersebut, sehingga harus memiliki kemampuan dan keterampilan atasnya sebagai bentuk usaha bela negara, dan ini bisa didapatkan oleh PNS melalui pembangunan budaya literasi.

\section{KESIMPULAN}

\section{A. Kesimpulan}

Usaha bela negara menjadi hak dan kewajiban semua warga negara. Penerapan kegiatan bela negara dapat dilakukan sesuai dengan profesi masing masing, termasuk bagi PNS di dalamnya. Usaha bela negara oleh PNS harus terus ditingkatkan dengan meningkatkan kualitas kemampuan dari PNS dan hal tersebut dapat ditunjang dengan membangun budaya literasi. Melalui budaya literasi setiap PNS akan lebih mudah mengetahui, mengidentifikasi dan mengatasi segala bentuk kegiatan negatif yang mengancam keutuhan bangsa dan negara.

\section{B. Rekomendasi}

1. Budaya literasi bagi PNS perlu dukungan kebijakan dari para pembina kepegawaian, sepeti pembuatan peraturan literasi PNS

2. Fasilitas pendukung budaya literasi harus memadai seperti pengadaan jaringan internet dan membuat pojok baca di setiap ruang

3. Sosialisasi budaya literasi harus dibuat lebih kreatif sehingga menarik, misal dengan mengadakan perlombaan membuat artikel ilmiah atau penelitian yang aplikatif dan diberikan penghargaan

4. Perlu dibentuk komunitas literasi dalam kalangan PNS, sehingga mendorong semagat literasi bagi PNS.

\section{REFERENSI}

Ainiyah, Nur. 2017. Membangun Penguatan Budaya Literasi Media dan Informasi Dalam Dunia Pendidikan. JPIl. Volume 2 Nomor 1. Hal : $65-77$.

Darmayanti, Riska. 2016. Membangun Budaya Literasi Informasi Bagi Masyarakat Kampus. Jurnal lara' Volume 10 Nomor 01. Hal : 92 101. 
Haryanti, Trini. 2014. Membangun Budaya Literasi Dengan Pendekatan Kultural Dan Komunikasi Adat. http://www.triniharyanti.id/2014/02/memba ngun-budaya-literasi-dengan.html (diakses 2 februari 2020).

Irianto, P.O dan Febrianti, L.Y. 2017. Pentingnya Penguasaan Literasi Bagi generasi Muda dalam menghadapi MEA. The 1 st Educational and Language Internatonal Conference Proceedings Center For International Language development of Unissula. Hal : 640 -647.

Kementerian Pemberdayaan Perempuan Dan Perlindungan Anak. 2018. Modul penguatan Prtisipasi Perempuan Bela Negara. Jakarta.

Kementerian Pendidikan dan Kebudayaan. 2017. Panduan Gerakan Literasi Nasional. Jakarta : Tim GLN Kemendikbud.

Mursalim. 2014. Penumbuhan Budaya Literasi Dengan Penerapan Ilmu Keterampilan Berbahasa (Membaca Dan Menulis). CaLLs. Volume 3 Nomor 1.Hal : $31-38$.

Permatasari, Ane. 2015. Membangun Kualitas Bangsa Dengan Budaya Literasi. Prosiding Seminar Nasional Bulan Bahasa UNIB. Hal : $146-156$.

Setiawan, Daryanto. 2018. Dampak Perkembangan Teknologi Informasi dan Komunikasi Terhadap Budaya. Jurnal SIMBOLIKA. Vol 4 Nomor 1. Hal : 62-72.

Subagyo, Agus. 2014. Bela Negara - Peluang Dan Tantangan di Era Globalisasi. Yogyakarta: Graha llmu.

Suroto, Hari. 2017. Menumbuhkembangkan Budaya Literasi Kalangan Pegawai Negeri Sipil di Papua. Jurnal JARLITBANG Pendidikan. Volume 3 Nomor 2. Hal : 319 327)

Widodo, Suwarno. 2011. Implementasi Bela Negara Untuk Mewujudkan Nasionalisme. Jurnal IImiah CIVIS. Volume I Nomor 1. Hal : 18 $-31$.

https://nasional.republika.co.id/berita/nasional /umum/17/12/12/p0uuby257-ada-800000situs-penyebar-hoax-di-indonesia https://nasional.kompas.com/read/2018/03/15 106475551/bin-60-persen-konten-mediasosial-adalah-informasi-hoaks 